ЯЦЬКОВА

Руслана Вікторівна ruslana15111999@ukr.net національного університету ім. Івана Франка
УдК 336.717 АНАЛІЗ ДІЯЛЬНОСТІ СИСТЕМ
ПЕРЕКАЗУ КОШТІВ В УКРАЇНI

\section{ANALYSIS OF THE ACTIVITY OF MONEY TRANSFER SYSTEMS IN UKRAINE}

DOI: https://doi.org/10.37634/efp.2021.3(1).6
БЛАЩУК-ДЕВ'ЯТКІНА

Наталя Зіновївна

nataliya.blashchuk-

devyatkina@lnu.edu.ua

YATSKOVA Ruslana Viktorivna - student, Ivan Franko Lviv National University

BLASHCHUK-DEVIATKINA Natalia Zinoviivna - PhD in Economics, Associate Professor of department, Ivan Franko Lviv National University

У статті досліджено теоретичні аспекти поняття «система переказу коштів» та виокремлено їх поділ на певні види. Подано аналіз діяльності платіжних систем в Украйні та обтрунтовано необхідність їх розвитку. Визначено, як система переказу коштів має позитивний вплив на економіку загалом. Проаналізовано переваги та недоліки систем переказів коштів зі сторін банку, країни та користувачів, а також надано рекомендації стосовно застосування основних чинників, щчо сприятимуть вдосконаленню цих систем.

$* * *$

The paper explores the theoretical aspects of the concept of a "system of funds transfer" and highlights their division into certain types. An analysis of the activity of payment systems in Ukraine was given and the necessity of their development was substantiated. It is determined how the system of money transfer has a positive impact on the economy in general. The advantages and disadvantages of money transfer systems were analyzed and recommendations have been made regarding the application of the main factors that will contribute to the improvement of these systems.

All of the above is the purpose of this paper.

The results of the conducted research show that now transfers through payment systems are becoming increasingly popular, but market development will depend entirely on several key factors: the development of infrastructure, legislation, and finance.

In conclusion, we can say that payment systems play one of the most important roles in the modern economy. They provide economic entities with the opportunity to make payments on liabilities that arise in the course of economic activity, and the rational organization of payment systems contributes to the smooth functioning of the financial sector. Reliable and efficient payment systems are a guarantee of the stable functioning of both the country's banking system and the economy in general.

Ключові слова: платіжна система, переказ коштів, грошовий оборот, трансакиія, банківська діяльність, ідентифікація та верифікачія клієнта

Keywords: payment system, money transfer, money turnover, transaction, banking, customer identification and verification

\section{ВСТУП}

Еволюція банківського сектору призвела до збільшення обсягів грошового обороту, покращення контролю грошового обігу, зменшення ризиків. Тому доцільним стало використання електронних грошей, створення систем електронних платежів та розрахунків. Позитивним $є$ те, що здійснення операцій грошового обігу не обмежується лише кордонами України, а дозволяє здійснювати перекази коштів майже в усі куточки світу, що значно збільшує прибуток банку як прямого учасника міжнародної платіжної системи, тим самим збільшуючи ВВП держави та надає можливість фізичним та юридичним особам користуватись цими послугами легко та без значних витрат.

Постійний розвиток інформаційного середовища, спостереження за досвідом розвинених країн, де раціональна організація платіжної системи сприяє вдосконаленню грошово-кредитних відносин, забезпеченню розвитку національного господарства, ефективному функціонуванню фінансової сфери в цілому спонукає до аналізу діяльності платіжних систем, а також визначення сучасного стану їх функціонування, що зумовлює актуальність обраної теми та доцільність про- ведення досліджень.

\section{Аналіз останніх досліджень та публікацій}

Загальні засади функціонування платіжних систем в Україні регулюються Законами України «Про Національний банк України», «Про банки й банківську діяльність», «Про платіжні системи та переказ коштів в Україні» [1].

Питання, що стосується платіжних систем розглядали такі українські науковці: Н.О. Коваль, М.В. Борщ, В.С. Волохата, А.А. Чубенко, О.О. Прокопенко, О.В. Рудинська, Н.А. Єрохіна та ін.

Даної теми у своїх працях торкалися також зарубіжні вчені: Р. Глен Габбард, М.Р. Енг, Е.М. Долан та ін.

У працях наведених вище представників викладено основні теоретичні засади, багато проблем функціонування платіжних систем, перспективи їх трансформації, проте дуже мало уваги приділено саме аналізу діяльності вітчизняних та міжнародних платіжних систем в Україні. А саме розкриття цього питання дасть змогу проаналізувати вплив платіжних систем на банківську діяльність в Україні та економіку загалом, порівняти рух коштів у межах нашої держави 3 транскордонним рухом коштів, розглянути ди- 
наміку співпраці України з іноземними державами у розрізі платіжних систем переказів коштів.

META статті - теоретичне обгрунтування систем переказів коштів, аналіз їх діяльності в Україні, визначення впливу на банківську систему. Також планується розглянути проблеми платіжних систем переказів зі сторін банку, країни та користувачів, а також визначити напрями удосконалення цих систем.

\section{МЕТОДИ ДОСЛІДЖЕННЯ}

У процесі дослідження застосовувалися такі загальнонаукові і спеціальні методи пізнання, як термінологічний метод, метод аналізу та синтезу, узагальнення та порівняння.

Інформаційною базою дослідження стали наукові праці вітчизняних учених, законодавство України, статистичні дані Національного банку України та матеріали наукових конференцій.

\section{РЕЗУЛЬТАТИ}

Віртуалізація та електронізація платежів в економіці зумовили звуження сутності поняття «платіжна система» як одного із найважливіших понять фінансового ринку взагалі та банківської системи зокрема. У Законі України «Про платіжні системи та переказ коштів в Україні» платіжна система визначається як платіжна організація, учасники платіжної системи та сукупність відносин, що виникають між ними при проведенні переказу коштів [1].

Також платіжну систему можна визначити як набір платіжних інструментів, банківських процедур i, як правило, міжбанківських систем переказу коштів, поєднання яких забезпечує грошовий обіг разом 3 інституційними та організаційними правилами та процедурами, що регламентують використання цих інструментів та механізмів [2].

В Україні виокремлюють наступні види платіжних систем:

- Державна платіжна система («Простір»);

- Платіжна система, платіжною організацією якої є банк: TELEGRAF (AT «ПРАВЕКС-БАНК»), PrivatMoney (АТ КБ «ПРИВАТБАНК»), «ГЛОБУС» (АТ «КБ «ГЛОБУС»), МY TRANSFER (АТ «Ощадбанк»);

- Платіжна система, платіжною організацією якої є небанківська установа (MOSST Payments, «Поштовий переказ»);

- Міжнародна карткова платіжна система: MasterCard, Visa;

- Міжнародна система переказу коштів: INTELEXPRESS, RIA, MoneyGram, Western Union;

- Внутрішньобанківська платіжна система: «За мить» (АТ «УКРСИББАНК»), EximCash (АТ «Укрексімбанк»), Unite Express (ПАТ «ЮНЕКС БАНК») [3].

Усі перелічені системи виконують функцію передачі потоку інформації, який містить деталі платежу і безпосередньо переказу грошових коштів, проте цей поділ $є$ не випадковим, адже кожна із груп має свої особливості.

Слід зазначити, що на початку другого кварталу 2020 р. діяла 41 система переказу коштів, з яких: 32 системи, створених резидентами, 9 систем, створених нерезидентами. У 2018 р. цифри були наступні: послуги надавали 35 систем переказу коштів, 3 яких: 28 систем, створені резидентами, 7 систем, створені нерезидентами, у 2019 р. було зареєстровано 39 платіжних систем переказу коштів, 3 яких: 31 система, створена резидентами, 8 систем, створені нерезидентами [4 - 6]. Тобто за останні три роки прослідковується тенденція зростання кількості платіжних систем переказу коштів, що є позитивним явищем, оскільки це збільшує швидкість та надійність платежів в економіці, що сприяє зростанню динамізму життя фізичних та юридичних осіб, розвитку інноваційних технологій.

За допомогою платіжних систем переказів коштів здійснено трансакцій:

- в межах України - 5541 млн дол. США у 2018 р., 7679 млн дол. США у 2019 р., 4551 млн дол. США за I півріччя 2020 p.;

- за межі України - 294 млн дол. США у 2018 р., 398 млн дол. США у 2019 році, 212 млн дол. США за І півріччя 2020 p.;

- в Україну - 2301 млн дол. США у 2018 р., 2271 млн дол. США у 2019 р., 1187 млн дол. США за I півріччя 2020 р. [6].

Оскільки за 2020 р. подано інформацію лише за I півріччя, то розглянемо графічно дані показники за 6 місяців кожного року, аби провести точне порівняння данних.

На рис. 1 за останні три роки чітко прослідковується тенденція зростання кількості переказів коштів із кожним наступним роком у межах України. Це $\epsilon$ позитивним явищем, оскільки чим більше користуються цим продуктом, тим більший прибуток буде у банків та небанківських установ, а тому й більший ВВП країни, що свідчить про розвиток економіки загалом.

На рис. 2 можна побачити, що Україна залишається країною-реципієнтом транскордонних переказів. Упродовж 1 півріччя 2020 р. сума коштів, отриманих в Україні з використанням міжнародних систем переказу коштів, майже в п'ять разів перевищує суму коштів, відправлених за іiі межі, але, не зважаючи на це, 3 кожним роком чітко прослідковується зростання кількості відправлених переказів з України закордон.

Також вищенаведені дані показують, що набагато більше користуються попитом перекази всередині держави, аніж транскордонні.

Впродовж 2018-2019 рр. ТОП - 5 країн, з яких здійснювались перекази в Україну залишались незмінними: США, Італія, Ізраїль, Російська Федерація та Польща, проте у 2020 р. на зміну Польщі стала Німеччина.

Ситуація $з$ країнами, у які українці відправляли кошти наступна: протягом 2018-2019 рр. ТОП-5 країнами були Російська Федерація, Китай, Грузія, Азербайджан, Узбекистан. У 2020 р. замість Китаю та Узбекистану переказ коштів здійснювався в Туреччину та Польщу.

Найбільш популярними міжнародними платіжними системами (МПС), через які здійснюються транскордонні перекази залишаються Western Union, MoneyGram, IntelExpress та RIA. Лідером серед цих МПС завжди був і залишається Western Union. Через дану систему здійснюється понад $55 \%$ трансакцій у розрізі всіх МПС [4-6]. 


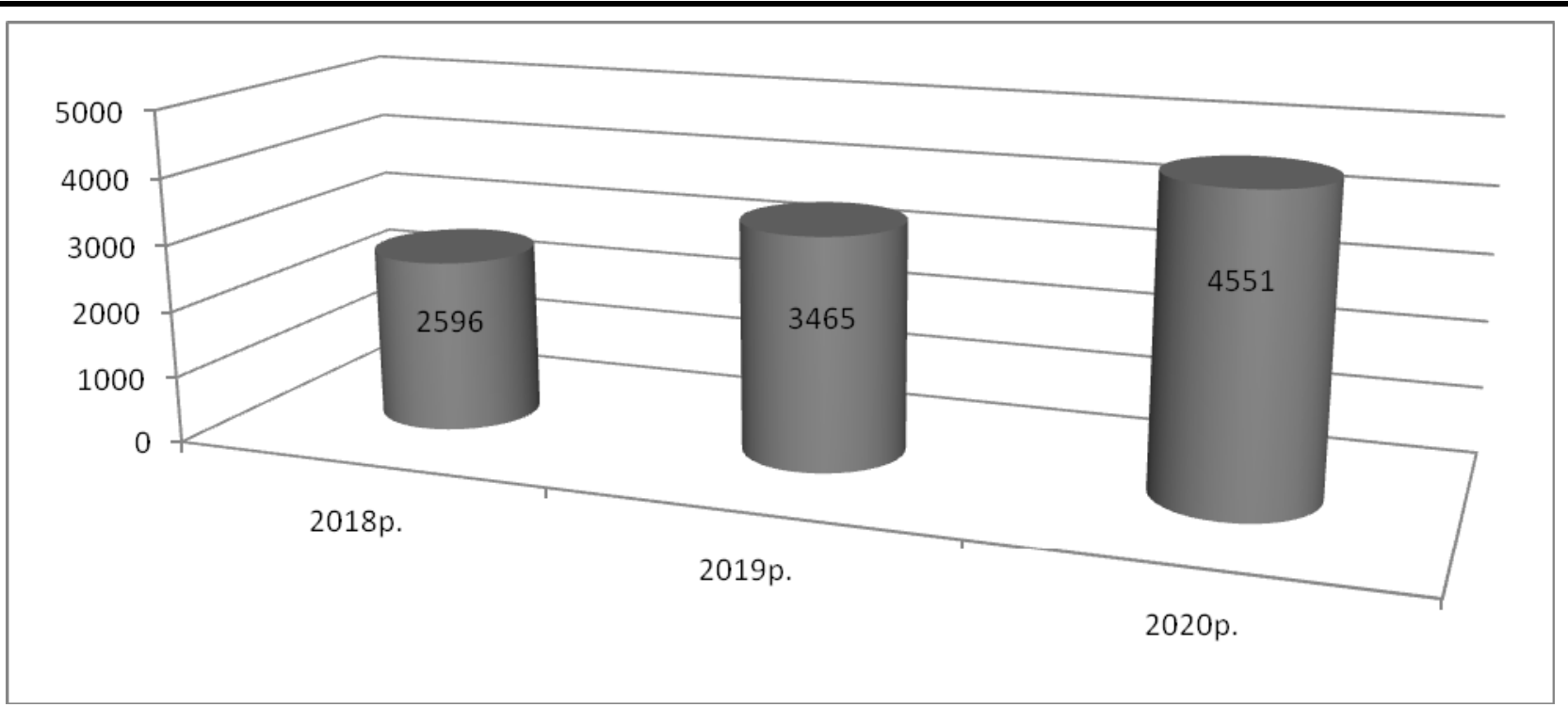

Рис. 1. Переказ коштів у межах Украӥни за 6 місящів 2018-2020 рр., млн дол. США [розроблено автором на основі джерела [6]]

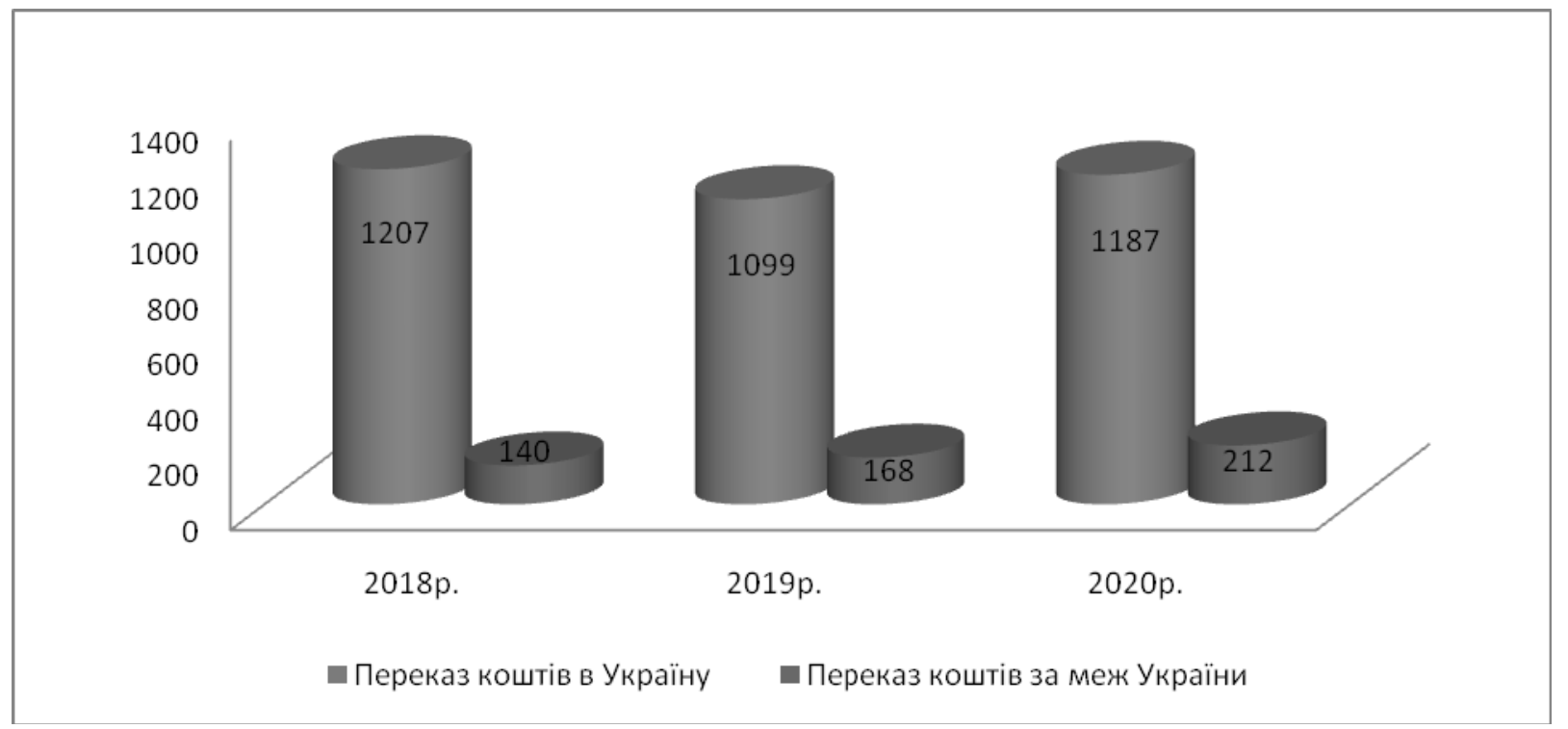

Рис. 2. Переказ кочтів в Україну та за ї̈ межі за 6 місяиів 2018-2020 рр., млн дол. США [розроблено автором на основі джерела [6]]

Не зважаючи на загалом стабільне й динамічне зростання кількості переказів коштів через платіжні системи, що свідчить про їх розвиток, існує низка недоліків, які можна розглядати з боків клієнтів, банків та країни.

Головними недоліками для клієнтів є:

- сплата комісії за переказ;

- обмеження в сумі;

- черги у касах, некомпетентність деяких працівників (якщо відправка/виплата переказу коштів відбувається через банківські установи);

- повернення/ затримка переказу в разі, якщо клієнт не пройшов внутрішню ідентифікацію клієнта у системі;

- неможливість відправки/отримання переказу, якщо клієнт не пройшов верифікацію в банку;

- збій у системах переказів, що спричиняє затримку коштів у платіжній системі.

Проте існують і переваги. Серед основних можна виокремити:
- швидкий переказ коштів без значних зусиль;

- можливість отримання інформації про статус переказу;

- можливість відправки коштів віртуально, або 3 банку на поточний рахунок клієнта;

- мала ймовірність ризиків, які можуть виникнути під час переказу коштів;

- контроль витрат;

- здійснення переказів згідно із законодавством України та програми фінансового моніторингу кожної платіжної системи, що майже унеможливлює шахрайство та робить відправку/отримання переказу безпечним (якщо є дотримання всіх вимог).

Якщо розглядати позитивні сторони для банків, то головною перевагою є, звичайно ж, отримання немалого прибутку (особливо якщо банк має субагентів). Для порівняння: середнє відділення банку може за місяць отримати приблизно 70000 грн, а здійснюючи перекази коштів через платіжні системи, банківська установа може отримати близько 200000 грн за той 
же період.

Негативним для банківської установи є формування щоденної звітності за переказами, бюрократія 3 документацією, збій у програмах, відповідальність за виплату/ відправку переказу.

Якщо говорити про державу, то тут перевагою є вдосконалення грошово-кредитних відносин, забезпечення розвитку національного господарства, ефективне функціонування фінансової сфери загалом. Недоліком для країни є лише постійне внесення змін у законодавство.

Однаково багато є переваг та недоліків, якщо розглядати їх у розрізі клієнта, банку та держави, але якщо взяти 3 цього лише найбільш глобальну складову - державу, то можна прийти до висновку, що все ж використання платіжних систем переказу коштів $є$ більше позитивним, ніж негативним.

\section{ВИСНОВКИ}

Платіжні системи відіграють одну з найбільш важливих ролей у сучасній економіці країни. Вони забезпечують суб'єктам економічної діяльності можливість здійснення розрахунків за зобов'язаннями, які 3'являються у процесі господарської діяльності, а раціональна організація роботи платіжних систем сприяє безперебійному функціонуванню фінансового сектору країни загалом і прискорює здійснення платежів у міжнародних і національних напрямах. Надійні й ефективні платіжні системи є гарантією стабільного функціонування як банківської системи країни, так і економіки загалом.

Аналіз діяльності платіжних систем переказів показав, що зараз цей продукт набирає все більшої популярності, проте розвиток ринку повною мірою залежатиме від декількох ключових чинників:

- по-перше, від розвитку відповідної технологічної платіжної інфраструктури;

- по-друге, від подальшого розвитку законодавства у сфері регулювання ринку, припинення шахрайства, захисту прав споживачів;

- по-третє, від підвищення якості послуг і маркетингової активності компаній, що надають дані послуги;

- по-четверте, від розвитку цифровізації у фінансовій сфері.

Якщо вищеперелічені дії будуть виконані належ- ним чином, то перспективи розвитку даної сфери очевидні, а тому й розвиток економіки також.

\section{Список використаних джерел}

1. Про платіжні системи та переказ коштів в Україні: Закон України за станом на 3 лип. 2020 р. / Верховна Рада України. URL: https://zakon.rada.gov.ua/laws/show/234614\#Text

2. Платіжна система України та стратегія іiі розвитку. URL: https://www.bestreferat.ru/referat-216752.html

3. Розширений пошук платіжних систем, учасників та операторів послуг платіжної інфраструктури. Національний банк України. URL: https://bank.gov.ua/ua/payments/paymentsystems

4. Діяльність в Україні систем переказу коштів. Національний банк України. 2018 p. URL: https://bank.gov.ua/admin_uploads/paper/PS2018.pdf?v=4

5. Діяльність в Україні систем переказу коштів. Національний банк України. 2019 p. URL:https://bank.gov.ua/admin_uploads/paper/PS_oversayt_pe r_kosht_graf_2019.pdf?v=4

6. Діяльність в Україні систем переказу коштів. Національний банк України. 2020 p. URL: https://bank.gov.ua/admin_uploads/paper/PS_oversayt_per_kos ht_graf_2020-H1.pdf?v=4

\section{$\underline{\text { References }}$}

1. About payment systems and funds transfer in Ukraine: Law of Ukraine as of July 3. 2020 / The Verkhovna Rada of Ukraine. URL: https://zakon.rada.gov.ua/laws/show/234614\#Text (in Ukrainian).

2. Payment system of Ukraine and its development strategy. URL: https://www.bestreferat.ru/referat-216752.html (in Ukrainian).

3. Advanced search of payment systems, participants and operators of payment infrastructure services. National Bank of Ukraine. URL: https://bank.gov.ua/ua/payments/paymentsystems (in Ukrainian).

4. Activity of money transfer systems in Ukraine. National Bank of Ukraine. 2018 p. URL: https://bank.gov.ua/admin_uploads/paper/PS2018.pdf?v=4 (in Ukrainian).

5. Activity of money transfer systems in Ukraine. National Bank of Ukraine. 2019 p. URL: https://bank.gov.ua/admin_uploads/paper/PS_oversayt_per_kos ht_graf_2019.pdf? $=4$ (in Ukrainian).

6. Activity of money transfer systems in Ukraine. National Bank of Ukraine. 2020 p. URL: https://bank.gov.ua/admin_uploads/paper/PS_oversayt_per_kos ht_graf_2020-H1.pdf?v=4 (in Ukrainian). 